
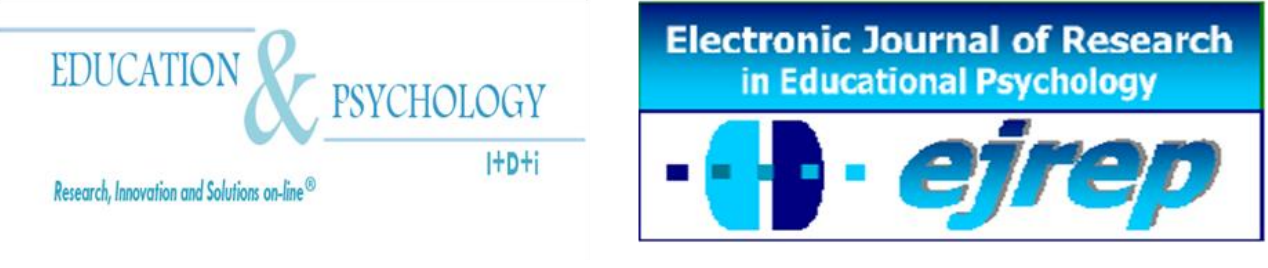

Editorial EOS

\title{
Attitudes of German Teachers and Students towards Public Online Ratings of Teaching Quality
}

\section{Arnold Hinz}

Institute of Educational Psychology and Sociology

University of Education. Ludwigsburg

\section{Germany}

Correspondence: Arnold Hinz. Institute of Educational Psychology and Sociology, University of Education Ludwigsburg, Reuteallee 46, D-71634 Ludwigsburg. Germany. E-mail: hinz@ph-ludwigsburg.de

(c) Education \& Psychology I+D+i and Editorial EOS (Spain) 


\begin{abstract}
Introduction. Rating scales evaluating the quality of teaching are widely used by academic institutions and have become increasingly popular in the World Wide Web. This study examines teachers' and teacher-education students' knowledge and experience with public online ratings of teaching quality and their attitude towards them.

Method. Based on focused interviews, a questionnaire was constructed. Data was collected from 225 teachers at seven schools and from 538 teacher-education students at four universities in Germany.

Results. $42 \%$ of all students questioned knew that they could evaluate their professors on MeinProf.de (the German version of RateMyProfessors.com), but only a total of $1.5 \%$ had posted one or more ratings on this website. Analysis of the data showed that teachers were more reserved towards public online ratings than teacher-education students $(p<.001)$, that senior teachers were more reserved about them than younger teachers $(p<.001)$, and that females were more reserved than males $(p<.01)$.
\end{abstract}

Conclusion. The results indicate that a teacher's age is the most important factor influencing attitudes towards public online ratings, which can presumably be attributed to an age-related difficulty in getting high ratings.

Keywords: teacher effectiveness evaluation; educational quality; teacher attitudes; teachereducation students; age differences.

Reception: 02/28/10 Initial acceptance: 05/12/11 Final acceptance: 07/11/11 


\section{Actitudes de Profesores y Estudiantes Alemanes ante las Evaluaciones Públicas en Internet de la Calidad de la Enseñanza}

\section{Resumen}

Introducción. Las evaluaciones de la calidad de la enseñanza basadas en un sistema de escalas son ampliamente usadas por instituciones académicas y se han vuelto muy populares en el world wide web. Este estudio examina la formación, conocimiento y experiencia de profesorado y alumnado de magisterio con este tipo de evaluaciones públicas en internet y sus opiniones respectivas.

Método. Se elaboró un cuestionario en base a unas entrevistas específicas. Los datos fueron recogidos por 225 profesores de siete escuelas y 538 estudiantes de magisterio en cuatro universidades alemanas.

Resultados. El 42\% de los estudiantes cuestionados sabían que podian evaluar a sus profesores en MeinProf.de (la versión alemana de RateMyProfessors.com), pero solo un 1.5\% dieron su voto una o varias veces en esta página web. Los análisis mostraron que los profesores se muestran mas reservados hacia esta forma de evaluación pública que los estudiantes de magisterio $(\mathrm{p}<.001)$, que los profesores mayores se muestran mas reservados que los profesores mas jóvenes ( $\mathrm{p}<.001$, y que las mujeres son mas reservadas que los hombres $(\mathrm{p}<.01)$.

Conclusión. Los resultados indican que la edad del profesor es el factor más determinante para su actitud hacia esta forma de evaluación pública, lo que presupone una desventaja para los mayores por la dificultad de conseguir una calificación alta.

Palabras Clave: Evaluación de la eficacia del profesor; calidad eduacional; opiniones de los profesores; estudiantes de magisterio; diferencia por edades. 


\section{Introduction}

The evaluation of teachers is an integral part of the contemporary educational system reform and teacher quality programs. Teacher evaluation schemes have been driven by demands for public accountability, control by the administration and for data collection as a resource for school development processes. In particular, international (OECD-) studies of student achievement (PISA, TIMMS) have strengthened the perception that education is a competitive system and that education systems are organisations that must strive to be efficient amongst the public, political leaders and educators (López, 2003). Around the world, evaluation has evolved from a voluntary activity to a compulsory task using standardized tests that are frequently administered by an outside agency (Larsen, 2005).

Rating questionnaires have been used as an inexpensive, timesaving means of evaluating the teaching practices of colleges and university faculty members. In U.S. institutions of higher learning that emphasize on teaching use student ratings of teaching effectiveness as the primary factor that determines a lecturer's success or failure in his or her career (Emery, Kramer, \& Tian, 2003). In Germany, voluntary and mandatory student evaluations of teaching quality are widely used at universities (even though many people have doubts about the desirability and utility of this form of evaluation). But these ratings are infrequently used in secondary schools. At the moment, students' evaluation of teachers and schools is being promoted by German school administrators and state education ministries.

Research on student evaluations of teaching effectiveness has often examined issues like the development of evaluation instruments, the student ratings' validity and reliability, as well as their potential bias (Chen \& Hoshower, 2003). Student evaluations have been subject to a number of criticisms. Some critics have argued that the ratings lack validity and exhibit a low correlation between student achievement and student ratings while having a high correlation between instructor expressiveness and student ratings, so that student evaluation of teaching effectiveness is just a popularity contest. The famed "Dr. Fox experiment" demonstrated that even professionals (psychiatrists, psychologists, social-worker educators and administrators) evaluated a presentation as excellent and thought they had learned something despite an irrelevant, meaningless and deliberately inconsistent content conveyed by a hired actor, called Dr. Fox (Naftulin, Ware \& Donnelly, 1973). Some critics claim that evaluations lead to lower standards and result in the "watering down" of course content because teachers believe that 
they will get higher ratings as a result. Finally, other critics maintain that there is no empirical evidence to suggest that evaluations actually improve teaching quality (Birnbaum, 1998; Emery, Kramer, \& Tian, 2003; Gray \& Bergmann, 2003; Greenwald \& Gillmore, 1997; Kulik, 2001; Sproule, 2002). Generally speaking, student evaluation of teaching quality is a very complex and controversial issue, and research findings about it are inconsistent. In spite of a broad debate about the different forms of bias in student evaluations (e.g. required versus elective courses, prior subject interest, class size, gender, race and physical appearance of the lecturer, leniency of grading, students in higher-level courses versus students in lower-level courses), the prevailing opinion seems to be that student evaluations provide a reliable and valid assessment of lecturers' teaching effectiveness, especially if measures of different courses are taken into account and if the evaluation is properly designed (Algozzine et al., 2004; Centra, 2003; Chen \& Hoshower, 2003; Penny, 2003).

The advent of the Internet has created a new form of student evaluation of teachers. This development has led to websites that include RateMyTeachers.com (United States, United Kingdom, Canada, Ireland, Australia, New Zealand), RateMySchool.org.uk (United Kingdom; teachers rate their school: building, location, resources, students, parents, colleagues), Studentsreview.com (United States), RateMyProfessors.com (United States, Canada, England, Scotland, Wales), Professorperformance.com (United States), MyFaveTeacher.com (India), RateYourProf.com/co.uk/co.in (United States, United Kingdom, India), ca.RateYourProf.com (Canada), kr.RateYourProf.com (South Korea), Reviewum.com (United States), Culpa.info (United States), MeinProf.de/at/ch (students' evaluations of professors in Germany, Austria, and Switzerland), Spickmich.de (pupils' evaluations of teachers and schools in Germany), Schulradar.de (parents' evaluations of schools in Germany), Note2be.com (France), StudenterTyckerTill.se (Sweden), Beoordeelmijnleraar.nl (The Netherlands), Belferia.pl, Epuls.pl/spokobelfer/ (evaluations of teachers in Poland), Ocen.pl/ (evaluation of professors in Poland), Votailprof.it (Italy), RateYourProfessor.gr (Greece), Schools.pomagalo.com, Moetodaskalo.com (evaluations of teachers in Bulgaria), Universiteta.com (evaluation of professors in Bulgaria), MarkMyProfessor.com (Hungary), Hodnoceniskol.cz (Czech Republic), or Campus.nikki.ne.jp/ (Japan). The common elements in all of these websites are that everyone can submit ratings and reviews for any teacher or professor, submissions are anonymous, and ratings and reviews can be read by everyone. 
The site "RateMyTeachers.com" was launched on August 2001. In this site, students can rate their teachers on a scale of 1 to 5 in terms of clarity, helpfulness and easiness; additional comments are also possible. The category "easiness" (e.g., "is it possible to get an A without too much work?") is not factored into the overall rating. Parents have the option to rate their children's teachers on expectations, difficulty, and respect. The website RateMyTeachers.com claims that it has 15 million ratings for 1.5 million teachers. The website "Spickmich.de" was launched on February 2007 by three students in Cologne, Germany. Schoolchildren (aged 6-18) can rate teachers and schools in 10 different categories; e.g. for teachers' fair grading, punctuality and apparel, humour and entertainment, professional expertise, motivation, and for schools technical equipment, facilities, head teachers, participation opportunities, sports facilities, and school cafeteria. A potential user must register for one school in order to read the results of this school (Spickmich). The website "MeinProf.de", which was launched on November 2005, serves as an evaluation instrument for students at universities. 400,000 assessments about 47,000 professors and 100,000 courses are available. All results and comments regarding professors can be read without any registration. In different countries (USA, Germany, France, UK), various attempts have been made to shut down online rating sites because some teachers regard these sites as a form of cyber-bullying. However, such claims have been dismissed on the grounds of free speech (only the French courts have ordered the web portal "Note2be" to cease its activities on pain of a huge pecuniary penalty; the website now operates from Brazil).

According to RateMyTeachers website, comments that contain vulgar words, are sexual in nature, concern physical appearance/disabilities or reference mental/alcohol/drug use, race, religion, ethnic background, sexual orientation or age will be deleted. The rater guidelines on RateMyProfessors say the site will delete references related to a professor's sex life (including sexual innuendo, sexual orientation or claims that the professor sleeps with students), claims that the professor shows bias for or against a student (or specific groups of students) or accusations that the professors are rating themselves or their colleagues. Nevertheless, comments like "you can't teach and have no control. How did you get a teaching job?" or "she is hysterical" are quite common. On Ratemyprofessors.com, a leading social psychologist was described as: He "looks like the devil, damn cocky too". The comments often are quite contradictory: “One of the best professors I've ever had in my life. Not cocky, just very talented", which was followed by: He "is cocky and full of himself. He thinks that he is 
the god of psychology, but he is not a very good teacher. Seems more interested in demonstrating how brilliant he is".

This article aims to focus on teachers' and teacher education students' attitudes towards public online ratings. Despite TV reports and press articles about RateMyTeachers.com, Spickmich.de, or Note2be.com, researchers have rarely investigated the online ratings of teachers, but analysed public online ratings of professors. Coladarci and Kornfield (2007) examined the relationship between the data on RateMyProfessors.com and official inclass SET ("student evaluation of teaching") data of University of Maine. They found a substantive correlation between RateMyProfessors and SET data $(r=.68)$. Davison and Price (2009), who administered a questionnaire to students at Appalachian State University, found that less than a third of students had posted on RateMyProfessors.com. An analysis of BleskeRechek and Michels (2010) revealed, contrary to their assumptions, marginal differences between students who had posted and had not posted (male students had posted more often than female). Furthermore, they did not find evidence to support their expectation that students use RateMyProfessors.com as a site to rant or rave. Kindred and Mohammed (2005) and Silva et al. (2008) analysed students' comments by content analysis. They found that students made more positive than negative comments about their instructors and that students' comments mostly focused on instructor characteristics and classroom experience and less on student development. Felton, Koper, Mitchell, and Stinson (2008) obtained the data for 6,852 professors from 369 institutions in the United States and Canada from RateMyProfessors.com and found significant correlations between quality and easiness $(r=.62)$ and between quality and hotness scores $(r=.64)$. Although easiness and hotness could be a function of quality, Felton et al. (2008) found more evidence to support the hypothesis that quality scores are a function of easiness and hotness.

Studies that examined faculty opinions about SET have rarely been conducted. This is a significant gap because SET will not increase teaching quality if teachers regard ratings as biased and as an act of injustice and humiliation. Stewart and Porter (2008) asked 2,000 teachers about their views of students' ratings of teaching effectiveness. $47 \%$ declared that they did not have a problem with students' ratings, while $40 \%$ opposed the practice. Unfortunately, there is not any available information about which kind of teachers (old/young, male/female, with high/low self-esteem, with high/low self-efficacy, competent/incompetent) are reserved towards SET. Sojka, Gupta, and Deeter-Schmelz (2002) examined differences in 
student and faculty opinions about student evaluations of teaching. Faculty members rated the validity of student evaluations much lower than students. $29 \%$ of the students surveyed versus $53 \%$ of the faculty members agreed with the statement that students give better ratings to instructors who teach less demanding courses. And faculty members agreed much more often than students that SET encouraged faculty members to grade easier (57\% and $12 \%$, respectively).

\section{Research Question and Hypotheses}

The aim of this survey was to examine teachers' and teacher-education students' knowledge of student online ratings of teaching quality, the frequency of postings on MeinProf.de and teachers' and teacher-education students' attitudes towards these ratings. It was assumed that only a few teacher-education students had already used online ratings like Spickmich.de (the German RateMyTeachers-website) or MeinProf.de (the German RateMyProfessors-website). Furthermore, this study tested the hypotheses that teachers would object more to public online ratings than teacher-education students, that senior teachers would be more critical of the ratings than younger teachers, and that teachers and students with higher teacher self-efficacy and with an above-average grade on final secondary school exam (Abitur in Germany) would have fewer objections to public online ratings.

\section{Method}

\section{Participants}

Complete data were collected from 763 subjects, 225 teachers $(37 \%$ male/63\% female) and 538 teacher-education students (16\% male/84\% female). Teachers were recruited from seven schools in the southern states of Germany (Baden-Württemberg and RhinelandPalatinate), with age differences ranging from 24 to 64 (median age $=49, S D=11.4$ ). This age distribution is representative for German teachers (according to the Federal Statistical Office: $M=48.1$ ). The teacher-education students were recruited from four universities (Heidelberg $53 \%$, Karlsruhe $32 \%$, Ludwigsburg $9 \%$, and Stuttgart $6 \%$ ), with age differences ranging from 18 to 48 (median age $=23, S D=3.4$ ). The response rate for teachers was $87 \%$, and $99 \%$ for students. 


\section{Design and Procedure}

Primarily, 16 focused (semi-structured) interviews were performed with teachers and teacher education students. The aim was to take an exploratory approach towards research subject and to prepare the structure in the form of a questionnaire. Emergent ideas and thoughts were documented, discussed and used as items. To measure the teachers' and students' attitudes towards online ratings and to test the above hypotheses, a questionnaire survey was conducted. The questionnaire was distributed at several teacher conferences and during lectures or seminars on pedagogics or educational psychology.

\section{Measures}

Participants filled out an anonymous 53-item self-report questionnaire. Four items inquired about gender, age, the number of years on the job/number of semesters, and final school exam grade (for students only). Ten of the items were from the Teacher Self-Efficacy Scale (e.g., "I am convinced that I am able to successfully teach all relevant subject content to even the most difficult students"; Schwarzer, Schmitz, and Daytner 1999; see also Faleye, 2008). Nine items delved into the respondents' experiences with and their opinion about the online ratings "Spickmich.de" and "MeinProf.de". 30 items were generated from the focused interviews using five-point Likert-type scales. For these items, a factor analysis was used to uncover the latent structure of the items. A four-factor solution, using varimax rotation, can be interpreted as "Expectance of positive outcomes of online ratings on teaching quality" (e.g. "Public feedback on the Internet makes it easier for teachers to see their specific weaknesses and to strengthen them", 7 items, Cronbach's alpha .89), "Expectance of negative outcomes of online ratings on teaching quality" (e.g. "Teachers could become envious of colleagues who receive good evaluations on the Internet", 7 items, Cronbach's alpha .81), "Expectance of collateral damages by the publicity of online ratings" (e.g. "Teachers are placed in a pillory when they are evaluated online", 5 items, Cronbach's alpha .76), and "Evaluation of the quality of online ratings" (e.g. "The quality of online ratings of teachers is poor since just one pupil could manipulate the results", 5 items, Cronbach's alpha $=.72$ ). 


\section{Results}

Website "MeinProf.de": Knowledge, Experience, Attitudes

The $42 \%$ of all questioned teacher-education students who were surveyed knew that students could evaluate their university or college professors on "MeinProf.de", while $58 \%$ were not aware of this online evaluation option. $81 \%$ of the students had never visited the German website "MeinProf.de" (where anyone can evaluate professors and other staff members of universities). A total of $12.3 \%$ had visited this website once, 3.6\% 2-5 times, $0.4 \%$ 6-10 times, and $0.2 \%$ more than 10 times. A total of $1.5 \%$ of all students had posted one or more ratings on "MeinProf.de", and $98.5 \%$ had never posted one. A total of $32.7 \%$ of the students said they would like to have the opportunity to make further online evaluations, 19.3 $\%$ declined, and $48 \%$ had no opinion about this question.

Website "Spickmich.de”: Knowledge, Experience, Attitudes

A total of $95.6 \%$ of all surveyed teachers and $73.1 \%$ of all surveyed teachereducation students had heard about the online ratings of teachers and schools. A total of 56.9 $\%$ of the teachers and $83.3 \%$ of the teacher-education students had never visited the website "Spickmich.de" (where pupils and secondary school students can evaluate teachers and the school), $20.4 \%$ of the teachers and $11.7 \%$ of the students had visited it once, $15.6 \%$ of the teachers and $4.1 \%$ of the students had visited it 2-5 times, $4.0 \%$ and $0.7 \%$, respectively, had visited it 6-10 times, and $3.1 \%$ and $0.2 \%$, respectively, had visited it more than 10 times.

Compared to the teacher-education students, teachers were more reserved towards the online ratings of teaching quality $\left(F_{(1,762)}=5.61, p<.001\right)$. A total of $26.2 \%$ of the teachers and $38.7 \%$ of the students said they thought that schoolchildren should be able to rate teachers and schools online, $53.8 \%$ of the teachers and $28.6 \%$ of the teacher-education students opposed this idea. Compared to teacher-education students, teachers were not as willing to accept the online ratings of themselves and of their teaching methods $\left(F_{(1,762)}=7.78, p<\right.$ $.001)$. A total of $34.2 \%$ of teachers and $51.7 \%$ of teacher-education students approved of schoolchildren's online evaluations of teachers and their teaching methods, $53.8 \%$ of the 
teachers and $27.0 \%$ of the students opposed this option, and the others had no opinion (12.0 $\%$ and $21.4 \%$, respectively).

Relationships between teachers' attitudes and gender, age, number of years on the job, and teacher self-efficacy

The most relevant finding is the relationship between the teachers' age and attitudes. Senior teachers were more reserved towards online ratings of teaching quality than young teachers. Senior teachers were less likely to approve of online evaluations $(r=.27, p<.001)$, were less likely to think that schoolchildren should have the chance to rate teachers online $(r$ $=.24, p<.001)$, were less likely to have positive expectations about the evaluation $(r=-.26, p$ $<.001)$ and were more likely to suspect collateral damages as a result of the public evaluations ( $r=.21, p=.002)$. These relationships remain significant if we take the partial correlation into account while controlling for the variable "number of years on the job". The relationship between teachers' attitudes and the number of years on the job becomes insignificant if we control this relationship for the variable "age". The difference between teachers and teacher-education students is insignificant, if we compare younger teachers $(<30$ years, $\mathrm{N}=$ 26) to teacher education students $\left(t_{(538)}=.11, p=.912\right)$. So the age of teachers is the strongest factor influencing the attitude towards online ratings. Figure 1 shows the distribution of the answers to the acceptance of online ratings for teacher-education students $(N=538)$, for teachers younger than $39(N=75)$, for teachers aged 39 to 53 years $(N=75)$, and for teachers older than 53 years $(N=72)$. 


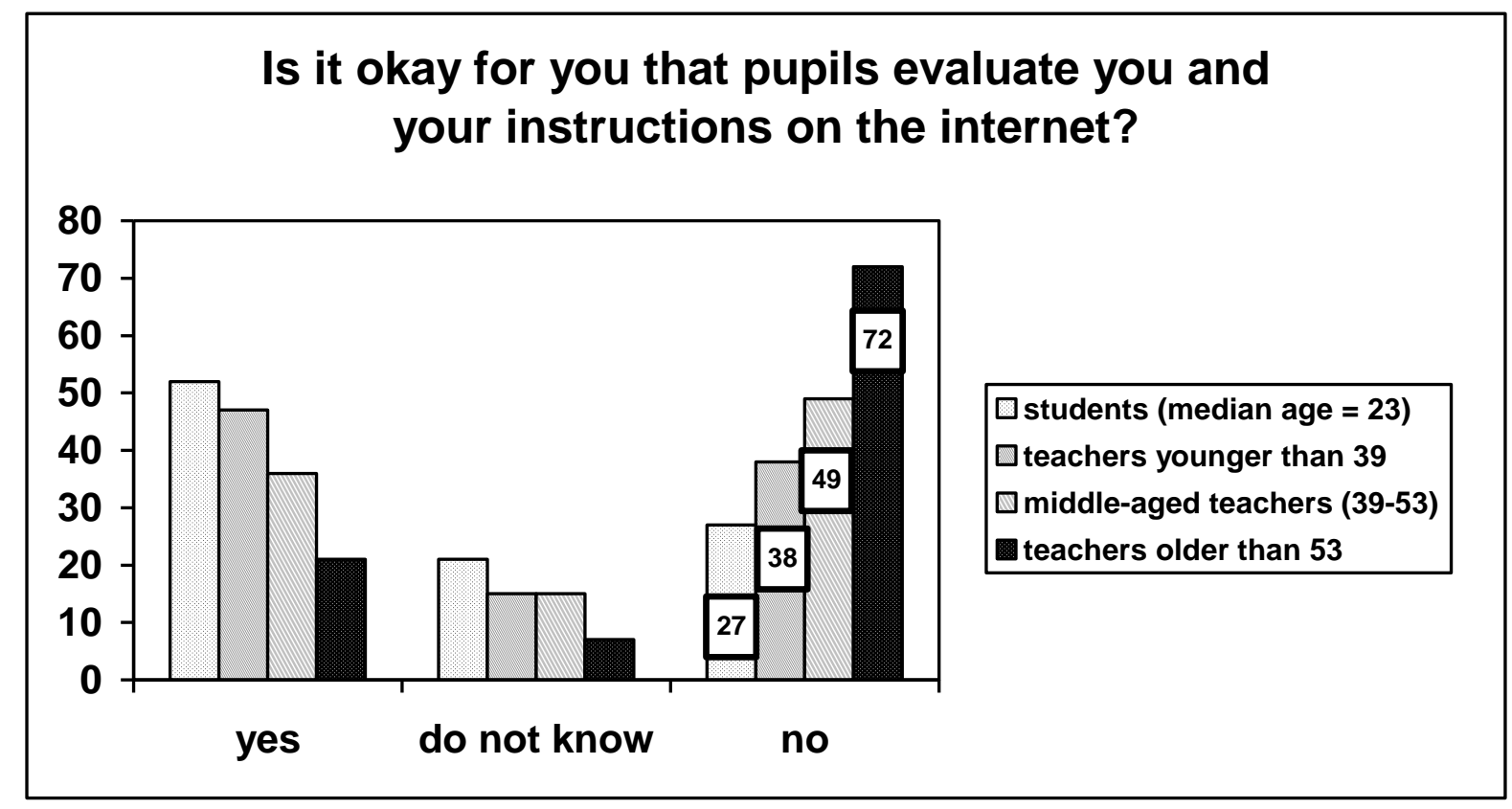

Figure 1: Percentage rate of acceptance (yes), indifference (do not know), and rejection (no) of online ratings for students and teachers of different ages

A relationship to gender was also uncovered. Female teachers were less likely to accept online ratings than male teachers $\left(t_{(221)}=3.18, p=.002\right)$, were less likely to think that students should have the opportunity to make online ratings $\left(t_{(221)}=2.61, p=.010\right)$, and more frequently criticised the quality of online ratings $\left(t_{(221)}=2.92, p=.004\right)$. Hardly any relationship between teachers' attitudes towards online ratings and teacher self-efficacy was found. Teachers with high teacher self-efficacy were less likely to expect collateral damages as a result of the publicity of online ratings $(r=-.19, p=.006)$. Yet there were no other significant relationships between teacher self-efficacy and teachers' attitudes towards student online ratings of teaching quality.

Relationships between students' attitudes and gender, age, number of semesters, teacher selfefficacy, and final school exam grade

Among teacher-education students no significant relationships were found between students' attitudes towards online ratings and the variables "age" and "number of semesters". Female students were less likely to accept the idea of being evaluated online than male students $\left(t_{(535)}=2.99, p=.003\right)$. The relationships between teacher self-efficacy and students' attitudes towards public online ratings were marginal. Students with high teacher self-efficacy expected negative outcomes from public online ratings less frequently $(r=-.15, p=.001)$, but 
there were no other significant relationships between teacher self-efficacy and students' attitudes towards public online ratings of teaching quality. Furthermore, no significant relationships between students' attitudes towards public online ratings of teaching quality and the final school exam grade (“Abiturnote" in Germany) were found.

\section{Discussion}

It is remarkable that only $1.5 \%$ of the surveyed teacher-education students had posted one or more ratings on "MeinProf.de", although $42 \%$ had heard about this website and 16.5 $\%$ had visited it. With regard to the use of public online ratings, a big difference can be observed between Germany and the US. It is highly probable that the outcome of student online ratings in Germany contains volunteer bias. Self-selected samples are biased because the decision to participate may be correlated with traits that affect the results. Students who have strong opinions will be more likely to devote the time to an online rating than those who have no preference.

More than half of the surveyed teachers and more than a quarter of the teachereducation students rejected public online ratings. The more reserved attitude of the teachers could be related to the real risk of being a victim of public online ratings, while teachereducation students considered it as something that actually will not affect them. Given that the difference between the younger teachers $(<30$ years $)$ and teacher-education students is not significant, leads one to think that the teachers' age is the most important factor influencing attitudes towards student online ratings. Based on this research, senior teachers do not have positive expectations about online ratings, and they more often suspect collateral damages.

Senior teachers' concerns probably have less to do with political persuasions than with real fears about the effect of the ratings. The physical attractiveness of the lecturer affects the assessment of teaching quality (halo effect). Many studies have demonstrated that instructors perceived as being physically attractive receive higher student evaluations (Bokek-Cohen \& Davidowitz, 2008; Feeley, 2002; Hamermesh \& Parker, 2005; Patzer, 2006; Riniolo et al., 2006), and that a statistical correlation exists between age and physical attractiveness, especially for women (Furnham, Mistry, \& McClelland, 2004; Mathes, Brennan, Haugen \& Rice, 1985, Teuscher \& Teuscher, 2007). Birnbaum (1998) asked 142 students to evaluate hypothetical classes. A total of $94.4 \%$ of the students gave higher evaluations to a fictitious "at- 
tractive, well-dressed, 36-year-old female with a nice personality" than to a "62-year-old male with a slight tremor (due to a previous stroke) who doesn't smile in class" (p. 6). Senior teachers more often have severe health problems, are significantly less attractive and have less energy. Due to these inevitable aspects of aging, senior teachers probably anticipate that they will receive negative or poor assessments, which reiterates the findings in this study. Consequently, senior teachers may view ratings of teaching quality as a source of humiliation, particularly at the end of an active, self-sacrificing teaching career. As a result, it can be regarded as an act of injustice to demand the individual evaluation of teaching quality. Should a 62year-old male earn less money, just because he is older, is less attractive, and has less energy or a severe health problem? School administrators and ministries regularly call for teaching quality to be evaluated, but they widely ignore the natural competitive disadvantages that senior teachers (and teachers with low physical attractiveness, health problems, or physical handicaps) have to bear. Therefore, it is not surprising that senior teachers more frequently reject ratings of teaching quality.

The more reserved attitude of female participants probably results from greater male self-confidence and greater female sensitivity to criticism. In a survey of a random sample of 821 teachers, Brimblecombe, Ormston, and Shaw (1996) found that female teachers felt three times more nervous than male teachers about an upcoming school inspection. If women are more frightened of being evaluated, it is reasonable for them to be less likely to accept the idea of evaluated online by schoolchildren or students. The more critical attitude of females towards online ratings could also be linked to gender bias in student evaluations. In an experimental design Arbuckle and Williams (2003) presented an age- and gender-neutral lecture (slides of a stick figure) and then evaluated it on teacher evaluation forms by varying age and gender of the teacher. Students (subjects) gave higher ratings to a young (under age 35) male teacher than to an old (over age 55) and/or (a) female teacher.

Contrary to the hypothesis, no significant correlation between final school exam grade (Abitur) and the attitudes towards online ratings has been found. The correlations between teacher self-efficacy and attitudes towards online ratings were marginally. These results could indicate that the attitude towards public online ratings was affected marginally or not at all influenced by the teaching quality of the teachers or teacher-education students. 


\section{Conclusion}

The active usage of websites similar to RateMyProfessors.com and RateMyTeachers.com is not in vogue at universities of education in the southern states of Germany in comparison to the US and other countries. Since only $1.5 \%$ of the surveyed teacher-education students had posted one or more ratings on "MeinProf.de", it is unlikely that these raters are a representative sample. While Bleske-Rechek and Michels (2010) did not find a bimodal distribution for the ratings on RateMyProfessors.com, Wolbring (2010) found more positive and particularly more negative ratings on MeinProf.de (so that the population was not normally distibuted). Additionally, it has to be taken into account that students can post multiple ratings and that nonstudents like angry neighbors, collegues, or the professors themselves can post ratings as well (Montell, 2006).

The present study must be seen as exploratory; several limitations should be noted. First, this study was limited to a non-random sample of 538 teacher-education students and 225 teachers in the southern states of Germany. Second, the use of the teacher self-efficacy scale and the final school exam grade are weak indices for teachers' and students' competence and quality, so it can not be answered whether teachers' and students' competence and quality have a relationship to the attitudes towards public online ratings. The third limitation concerns the insight in the perceptions and attitudes of senior teachers. At least for this sample, the results suggest that the age of the teachers has a strong influence on their attitudes towards public online ratings of teaching quality. But this study does not allow for gaining insight into the motives, convictions, reservations and willingness of senior teachers. More research is needed to expand the results of this study to other populations, and to elucidate senior teachers' attitudes.

If evaluations are assessments of student satisfaction (and only partly of teaching effectiveness) and if physically attractive and expressive lecturers get higher ratings, then older lecturers have a lower chance of getting good evaluations. The demand for evaluation was influenced heavily by the neo-liberal policy of introducing business management practices to education. It may be that policymakers, school administrators, headmasters, and principals have forgotten that there is a large shortage of senior people in the industry and that school politics can not be modelled on the merciless treatment of the older people involved. If SET should be a means for enhancing teaching and not for bureaucratic ends, further research is 
needed that generates more information on teachers' attitudes towards student ratings, especially on senior teaches' attitudes and their demand for justice.

\section{Acknowledgements}

I would like to thank all students, teachers, and headmasters who supported me and participated in this study. Special thanks are due to the staff of the Educational Centre Weissacher Tal (Bize), and the Hirschberg School, Ludwigsburg. 


\section{References}

Algozzine, B., Beattie, J., Bray, M., Flowers, C., Gretes, J., Howley, L., Mohanty, G. \& Spooner, F. (2004). Student evaluation of college teaching: A practice in search of principles. College Teaching, 52, 134-141.

Arbuckle, J. \& Williams, B. D. (2003). Students' perceptions of expressiveness: age and gender effects on teacher evaluations. Sex Roles, 49, 507-516.

Birnbaum, M. H. (1998). A survey on faculty opinions concerning student evaluations of teaching. Retrieved from: http://psych.fullerton.edu/mbirnbaum/faculty3.htm (accessed July, 2011).

Bleske-Rechek, A. \& Michels, K. (2010). RateMyProfessors.com: Testing assumptions about student use and misuse. Practical Assessment, Research \& Evaluation, 15(5), 1-12.

Bokek-Cohen, Y. \& Davidowitz, N. (2008). Beauty in the classroom: Are female students influenced by the physical appearance of their male professors? Journal of Education and Human Development, 2(1). Retrieved from: http://www.scientificjournals.org/journals2008/articles/1371.pdf(accessed July, 2011).

Brimblecombe, N., Ormston, M. \& Shaw, M. (1996). Gender differences in teacher response to school inspection. Educational Studies 22: 27-40.

Centra, J. A. (2003). Will teachers receive higher student evaluations by giving higher grades and less course work? Research in Higher Education, 44, 495-518.

Chen, Y. \& Hoshower, L. B. (2003). Student evaluation of teaching effectiveness: an assessment of student perception and motivation. Assessment and Evaluation in Higher Education 28, 71-88.

Coladarci, T. \& Kornfield, I. (2009). RateMyProfessors.com versus formal in-class student evaluations of teaching. Practical Assessment, Research \& Evaluation, 12(6), 1-15.

Davison, E. \& Price, J. (2009). How do we rate? An evaluation of online student evaluations. Assessment \& Evaluation in Higher Education, 34, 51-65.

Emery, C. R., Kramer, T. R. \& Tian, R. G. (2003). Return to academic standards: a critique of student evaluations of teaching effectiveness. Quality Assurance in Education, 11, 3746.

Faleye, B. A. (2008). Reliability and factor analysis of a teacher efficacy scale for Nigerian secondary school teachers. Electronic Journal of Research in Educational Psychology, $16,823-846$.

Feeley, T. H. (2002). Evidence of halo effects in student evaluations of communication instruction. Communication Education 51, 225-236. 
Felton, J., Koper, P. T., Mitchell, J. \& Stinson, M. (2008). Attractiveness, easiness, and other issues: Student evaluations of professors on Ratemyprofessors.com. Assessment and Evaluation in Higher Education, 33, 45-61.

Furnham, A., Mistry, D. \& McClelland, A. (2004). The influence of age of the face and the waist to hip ratio on judgements of female attractiveness and traits. Personality and Individual Differences 36, 1171-1185.

Gray, M. \& Bergmann, B. (2003). Student teaching evaluations: inaccurate, demeaning, misused. Retrieved from: http://www.aaup.org/AAUP/pubsres/academe/2003/SO/Feat/gray.htm (accessed July, 2011).

Greenwald, A. G. \& Gillmore, G. M. (1997). No pain, no gain? The importance of measuring course workload in student ratings of instructions. Journal of Educational Psychology, $89,743-751$.

Hamermesh, D. S. \& Parker, A. M. (2005). Beauty in the classroom: instructors' pulchritude and putative pedagogical productivity. Economics of Education Review, 24, 369-376.

Kindred, J. \& Mohammed, S. N. (2005). 'He will crush you like an academic ninja': Exploring teacher ratings on ratemyprofessors.com. Journal of Computer-Mediated Communication, 10 (3), article 9. Retrieved from:

http://jcmc.indiana.edu/vol10/issue3/kindred.html (accessed July, 2011).

Kulik, J. A. (2001). Student ratings: validity, utility and controversy. New Directions for Institutional Research, 27, 9-25.

Larsen, M. A. (2005). A critical analysis of teacher evaluation policy trends. Australian Journal of Education, 49, 292-305.

López, I. G. (2003). A look at quality academic training: the university students' point of view. Electronic Journal of Research in Educational Psychology, 1(2), 1-22.

Mathes, E. W., Brennan, S. M., Haugen, P. M. \& Rice, H. B. (1985). Ratings of physical attractiveness as a function of age. The Journal of Social Psychology, 125, 157-168.

Montell, G. (2006). The art of the bogus rating. The Chronicle of Higher Education. Retrieved from: http://chronicle.com/article/The-Art-of-the-Bogus-Rating/46887/ (accessed July, 2011).

Naftulin, D. H., Ware, J. E. \& Donnelly, F. A. (1973). The Doctor Fox lecture: a paradigm of educational seduction. Journal of Medical Education, 48, 630-635.

Patzer, G. L. (2006). The Power and Paradox of Physical Attractiveness. Boca Raton, Florida: Brown Walker Press. 
Penny, A. R. (2003). Changing the agenda for research into students' views about university teaching: four shortcomings of SRT research. Teaching in Higher Education, 8, 399411.

Riniolo, T.C., Johnson, K. C., Sherman, T. R. \& Misso, J. A. (2006). Hot or not: Do professors perceived as physically attractive receive higher student evaluations? The Journal of General Psychology, 133, 19-35.

Schwarzer, R., Schmitz, G. S. \& Daytner, G. T. (1999). The Teacher Self-Efficacy scale. Retrieved from: http://userpage.fu-berlin.de/ health/teacher_se.htm (accessed July, 2011).

Silva, K. M., Silva, F. J., Quinn, M. A., Draper, J. N., Cover, K. R. \& Munoff, A.A. (2008). Rate my professor: Online evaluations of psychology instructors. Teaching of Psycho$\log y, 35,71-80$.

Sojka, J., Gupta, A. K. \& Deeter-Schmelz, D. R. (2002). Student and faculty perceptions of student evaluations of teaching: A study of similarities and differences. College Teaching, 50, 44-49.

Sproule, R. (2002). The underdetermination of instructor performance by data from the student evaluation of teaching. Economics of Education Review, 21, 287-294.

Stewart, W. \& Porter, N. (2008). Happy to be rated. TES (Times Educational Supplement) Cymru, 14 March 2008. Retrieved from: http://www.tes.co.uk/article.aspx?storycode=2593678 (accessed July, 2011).

Teuscher, U. \& Teuscher, C. (2007). Reconsidering the double standard of aging: Effects of gender and sexual orientation on facial attractiveness ratings. Personality and Individual Differences, 42, 631-639.

Wolbring, T. (2010). Why the attempt to separate productivity and discriminiation effects on students' evaluations of teaching fails - Selective samples, missing mediator variables and confounding of effects. Kölner Zeitschrift für Soziologie und Sozialpsychologie, 62, 317-326. 
Arnold Hinz

[This page intentionally left blank] 